Article

\title{
Interactions between Lake-Level Fluctuations and Waterlogging Disasters around a Large-Scale Shallow Lake: An Empirical Analysis from China
}

\author{
Zongzhi Wang ${ }^{1, *(\mathbb{D}}$, Kun Wang ${ }^{1,2}$, Kelin Liu $^{1}$, Liang Cheng ${ }^{1}$, Lihui Wang ${ }^{3}$ and Ailing Ye ${ }^{1}$ \\ 1 State Key Laboratory of Hydrology-Water Resources and Hydraulic Engineering, \\ Nanjing Hydraulic Research Institute, Nanjing 210029, China; wkun0101@163.com (K.W.); \\ klliu@nhri.cn (K.L.); Chenglianghfut@126.com (L.C.); yal_yizumi@163.com (A.Y.) \\ 2 College of water Conservancy and Hydropower Engineering, Hohai University, Nanjing 210098, China \\ 3 College of Civil Engineering, Fuzhou University, Fuzhou 350002, China; wlh0411@yahoo.com.cn \\ * Correspondence: wangzz77@163.com; Tel.: +86-138-1386-2762
}

Received: 29 December 2018; Accepted: 10 February 2019; Published: 13 February 2019

check for updates

\begin{abstract}
Waterlogging disasters in the lakeside areas of shallow lakes that located in plain regions are sensitive to lake-level fluctuations. However, there are very few studies on the influences of lake-level fluctuations on waterlogged lakeside areas from a large lake basin perspective. This paper proposes an integrated hydrodynamic model employing the MIKE software to contribute to the existing literature by filling the gap constituted by the lack of an estimation of the impacts of lake-level fluctuations on waterlogging disasters by relevant models. First, a coupled one-dimensional and two-dimensional hydrodynamic model is established to simulate the waterlogging routing in the lakeside area around Nansi Lake (NL) in addition to the flood routing in NL and its tributaries. Second, the model is calibrated and verified by two measured flood events in July 2007 and July 2008; the results indicate that the model can correctly simulate the drainage process of pumping stations in the lakeside area, as well as the interactions between the waterlogging drainage and lake-level fluctuations. Third, the process of waterlogging in the lakeside area of NL is simulated under different rainfall events and initial lake-level conditions. Fourth, based on the results of the model, this paper illustrates the influences of lake-level fluctuations on the waterlogged area around the lake, as well as the different responses of waterlogging in different areas to lake-level fluctuations in NL and the main cause for these differences. Finally, based on the results of the model, this paper presents some implications for waterlogging simulations and drainage system design.
\end{abstract}

Keywords: flood control and disaster reduction; coupled hydrodynamic model; waterlogging disaster; Nansi Lake

\section{Introduction}

It is estimated that there are more than 117 million lakes greater than $0.002 \mathrm{~km}^{2}$ on the surface of the Earth [1]. Due to their important abilities to retain floodwater, as well as store and provide freshwater, lakes are the essential components of the hydrological and biogeochemical water cycles and have an influence on the many aspects of ecology, economy, and human welfare in lake basins [2]. As the decisive indicator of lake hydrological cycles, water-level fluctuations (WLFs) have an overriding effect on the ecology, function, and management of shallow lake basins [3,4]. These shallow lakes in the plain area always have numerous rivers that flow into the lake, and their flow regimes have a sensitive response to WLFs because of the gentle slope and low topography. In addition, the drainage efficiency decreases gradually due to the blocking of rising lake level, and as a result, the waterlogged area in the lake basin increase. 
According to statistics, weather events account for $62 \%$ of all of the events recorded as natural disasters, and floods and storm events account for $60 \%$ of weather events [5]. The lakeside area around shallow lakes, especially for lakes in the plain area, will experience more serious waterlogging disasters with greater severity in the future due to the combined effects of climate change, rapid urbanization, and the insufficient capacity of the rainstorm drainage system. Accurately simulating the process of waterlogging in shallow lake basins to reveal the response relationship between WLFs and waterlogged areas has a great significance for the scientific arrangement of drainage engineering and correct decision making regarding flood control. Due to the lake level being one of the decisive factors in the functioning of lakes, especially shallow lakes, the effects of lake-level fluctuations on the water quality and biota in lakes have been documented by many papers [6-10]. Meanwhile, in addition to influencing the ecosystem of lakes, lake-level fluctuations also have obvious effects on the interactions between lakes and other bodies linked to them. Rasid and Hufferd [11] noted that the lake level has a significant effect on the flood hazards in the lakeside area of Lake Superior. Clausen and Johnson [12] reported the response of sediment and nutrient retention within wetlands to lake-levels. Luo et al. [13] noted that a higher lake level will decrease the drainage discharge of a pumping station in a lakeside area. Guo et al. [14] analyzed the variations in the hydrologic and climatic characteristics of the Poyang Lake Basin, and presented the relationship between the regularity of drought and waterlogging and the water level of the Yangzi River. Li et al. [15] analyzed the regularity and influencing factors of waterlogging disasters in the Poyang Lake Basin based on the historical data, and noted that the rise of water level in the Yangzi River is an important factor for the aggravation of waterlogging disasters in the Poyang Lake Basin, China. However, the quantitative research on the influences of lake-level changes to waterlogging in lakeside areas has seldom been reported. On the other hand, some methods that analyzed flooding and waterlogging have been developed and used in recent decades. Based on the historical data and statistical methods to analyze the spatial and temporal characteristics and the causes of waterlogging disasters in lake basins is the premise to understanding the occurrence mechanism of waterlogging disasters, and is also essential for predicting the macroscopic development trends of the flooding and waterlogging disasters [16-20]. The Mann-Kendall test and Sen's slope test are popular methods in the field of trend analysis that have been widely used around the world [21-25]. However, due to the limitation of the monitoring measures and the accuracy of historical data, it is difficult to accurately grasp the process of waterlogging, and thus, these researches of waterlogging have switched from statistical analysis to quantitative research, thereby turning from the statistical method based on historical data to directly simulating the spatial and temporal process of flooding and waterlogging by establishing mathematical models [26-29]. Early waterlogging simulations were mainly concentrated on urban areas. Some researchers coupled hydrological models, such as the Storm Water Management Model (SWMM), with two-dimensional (2D) hydrodynamic models to simulate the process of rainstorm waterlogging in urban areas [30,31]. The SWMM can make up for the shortcomings of hydrological models, which cannot provide information on the waterlogging area and submerged depth directly. Hsu et al. [32] established an urban inundation model through a coupled SWMM and a two-dimensional diffusive overland-flow model, and simulated the waterlogging drainage under a design storm in the Taipei Basin. Bisht et al. [25] combined the SWMM, MIKE ERBAN (a model developed by Danish Hydrological Institute), and MIKE21 to simulate rainstorm waterlogging in West Bengal, India. Hydrodynamic models can obtain flooding and waterlogging information with a high spatial resolution, and have become an effective tool for simulating and predicting the flooding processes in recent years $[33,34]$. Several scholars have used hydrodynamic models to simulate the flooding of rainstorm waterlogging in different areas based on multi-scenario simulations to access the risks and the law of the waterlogging $[17,35,36]$.

However, there are very few reports that feature quantitative analyses of the influences of WLFs on waterlogging around lakes from the whole basin perspective by multi-scenario modeling [37]. An important gap that appears in the literature, apart from a few papers, is the lack of an estimation of the increasing extent of waterlogged areas caused by lake-level rise by relevant models. 
This paper proposes a coupled hydrodynamic model with a one-dimensional model (1D model) and two-dimensional model (2D model) to contribute to the existing literature by considering this gap.

The Nansi Lake Basin (NLB) in the Huai River Basin, China, is chosen as the research area in this study. The reason why we chose the Nansi Lake Basin is that Nansi Lake is the largest freshwater lake in northern China with a water depth $1.5 \mathrm{~m}$, and the lakeside area around Nansi Lake is a plain area where waterlogging occurs frequently approximately every three to five years [38]. Furthermore, due to climate change, the lake temperature in this region increased significantly between 1985-2009 [39-41]. Extreme rainfall in the region may increase in the future. This paper attempts to address three issues. (1) How can the interactions among the lake, the rivers flowing into the lake, and the waterlogging in the lakeside area be simulated via a coupled hydrodynamic model? (2) What are the influences of lake-level fluctuations on the waterlogging in the lakeside area? (3) What is the difference in the degree of waterlogging among different areas around Nansi Lake in response to lake-level fluctuations? What were the main drivers for this difference?

The remainder of this paper is structured as follows. Section 2 introduces the study area and the collection and processing of data. Section 3 depicts the Nansi Lake Flooding and Waterlogging Simulation Model (NLFWSM) framework and its calibration and verification. Section 4 presents the results and discussions, and some conclusions and policy implications for decision makers are outlined in Section 5.

\section{Study Area and Data}

\subsection{Study Area}

The Nansi Lake Basin is located at the junction of Shandong, Jiangsu, and Henan Provinces in the Huaihe River Basin with a catchment area of $31,700 \mathrm{~km}^{2}$. The western Nansi Lake is the flood plain of the Yellow River, which is spread out over an area of $21,900 \mathrm{~km}^{2}$. The elevation of the western Nansi Lake gradually decreases from west to east with a slope between $1 / 5000-1 / 20,000$, while the elevation of the lakeside area is approximately $33.5 \mathrm{~m}$ (above sea level). The eastern Nansi Lake is a hilly region with an area of $8500 \mathrm{~m}^{2}$, and the slope is between 1/1000-1/10,000. There are 53 tributary rivers; among them, 25 are distributed throughout the western Nansi Lake, mainly including the Liangji River, Zhuzhaoxin River, Dongyu River, and Fuxin River, while the rest are located in the eastern Nansi Lake region, including the Guangfu River, Si River, Baima River, and Xinxue River [38]. Figure 1 shows the generalized water system of the Nansi Lake Basin. The proportion of economic crops and food crops in the Nansi Lake Basin is 45.1:54.9. Among the main agricultural products, wheat accounts for $23.40 \%$, corn accounts for $10.78 \%$, peanuts account for $6.49 \%$, rice accounts for $4.20 \%$, soybeans account for $2.79 \%$, watermelon accounts for $2.73 \%$, and sweet potatoes account for $2.57 \%$.

Nansi Lake $\left(34^{\circ} 270^{\prime} \mathrm{N}-35^{\circ} 200^{\prime} \mathrm{N}, 116^{\circ} 34^{\prime} \mathrm{N} \sim 117^{\circ} 21^{\prime} \mathrm{N}\right)$ is a long and narrow lake with gentle terrain, and it consists of Nanyang Lake, Dushan Lake, Shaoyang Lake, and Weishan Lake from north to south [42]. Nansi Lake is a typical shallow lake with a water surface area of $1266 \mathrm{~km}^{2}$ and a water depth of $1.5 \mathrm{~m}$ under normal water level conditions. A comprehensive project consisting of sluices and one dam (called Erji dam) was built at the center of Nansi Lake and divided the lake into two parts: namely, the upper lake and the lower lake. The catchment area of the upper lake is $27,000 \mathrm{~km}^{2}$, which accounts for $85 \%$ of the total basin area. The low-lying region around Nansi Lake mainly refers to the ground elevation below $36.7 \mathrm{~m}$ (above sea level) with a total area of approximately $3969 \mathrm{~km}^{2}$. Due to the low terrain and the high levees along Nansi Lake and its tributary rivers, waterlogging in the lakeside around Nansi Lake can be drained into rivers or Nansi Lake only by pumping stations. The infiltration of Nansi Lake causes a high groundwater level that is below the ground by only $\sim 0.2-0.3 \mathrm{~m}$ in the lakeside area; therefore, the runoff yield rate is large. In the case of a rainstorm, due to influences by the soaring water levels of the rivers and Nansi Lake, the pumping drainage efficiency will decrease, and thus, waterlogging disasters will be more serious. According to statistical data, the Nansi Lake Basin encounters a waterlogging disaster approximately every three to five years on 
average, and many severe disasters occurred in the last 60 years, including in 1954, 1957, 1963, 1974, 1982, 1990, 1991, 1993, 2000, and 2003.

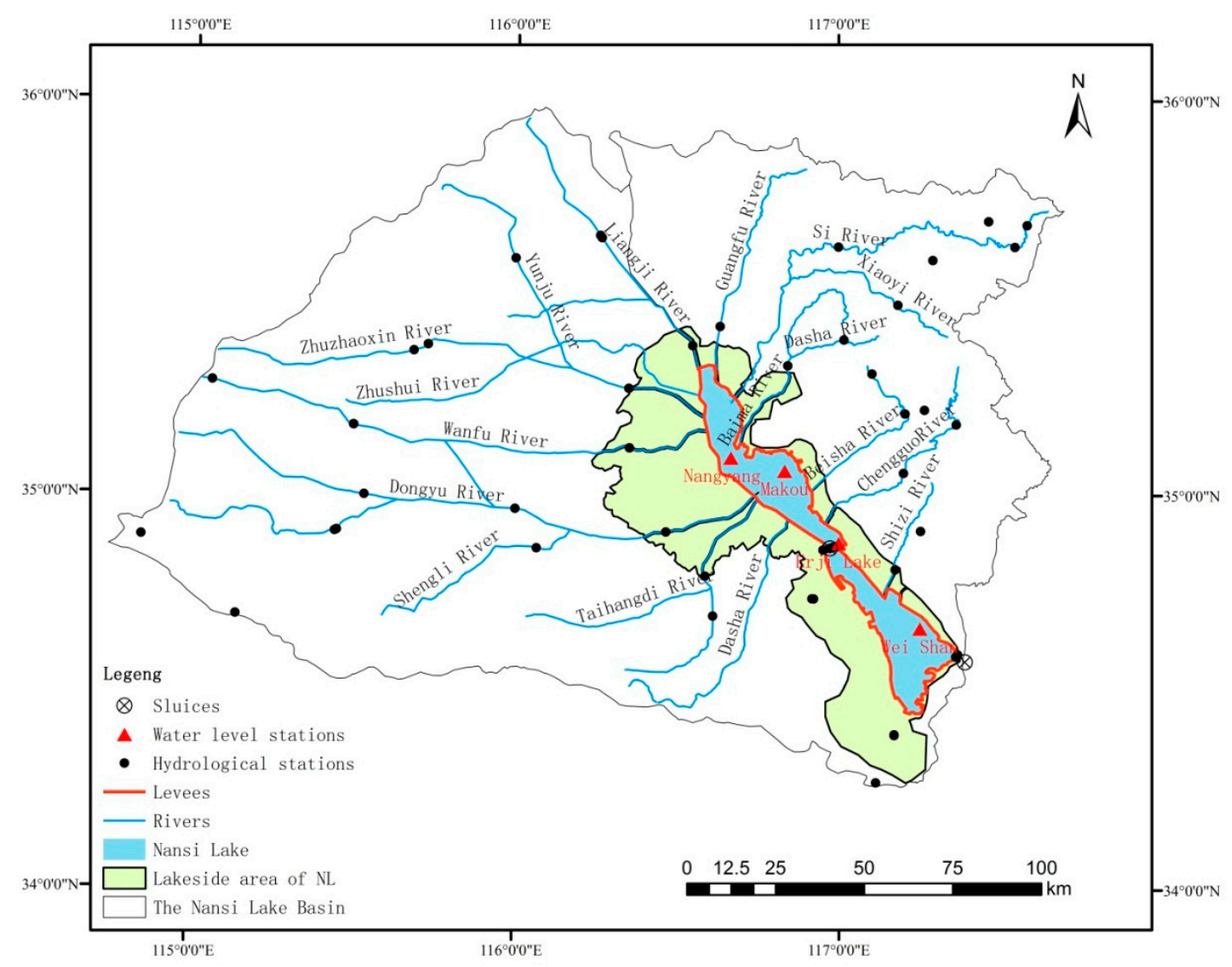

Figure 1. The generalized water system map of the Nansi Lake Basin.

\subsection{Data Collection}

The data utilized in this paper include elevation data, hydrological data, meteorological data, and hydraulic engineering data.

(1) The digital elevation model (DEM) and river channel bathymetry were provided by the Planning and Design Institute of the Huaihe Basin Hydraulic Management Bureau in Shandong Province, China. The DEM of the lakeside and Nansi Lake in a 2D model were derived from 1:7000 topographic maps of 2013, and the river channel bathymetry used in the 1D model was reflected by 550 cross-sections separated by distances between $500-1000 \mathrm{~m}$.

(2) The hydrological data originated from the Shandong Provincial Hydrology Bureau. The data mainly includes the discharge processes of typical floods in the upper boundaries of rivers and daily rainfall records at seven rainfall stations, namely, Huayu, Liangshanzha, Wanglu, Wanggudui, Wangzhong, and Xuecheng. Each station has daily precipitation records of approximately 30 to 50 years. The daily water level records of four stations, namely, Nanyang, Makou, Erji Lake, and Weishan (shown in Figure 1), have also been provided.

(3) The meteorological data were downloaded from the National Meteorological Scientific Data Sharing Service Platform (http://data.cma.cn/), and the data include daily records of numerous meteorological parameters, including the wind field and evapotranspiration.

(4) The hydraulic engineering data were provided by the Planning and Design Institute of the Huaihe Basin Hydraulic Management Bureau in Shandong Province, China. The data includes the location and drainage capabilities of pump stations, the locations and sizes of flood control embankments, and the hydraulic parameters of sluices. 


\section{Methodology: Establishment of NLFWSM}

\subsection{Model Structure}

We select the MIKE software, which was developed by the Danish Hydrological Institute [43] and has been applied widely $[25,33,34]$, as a modeling tool to establish the NLFWSM. The MIKE 11, MIKE 21, and MIKEFLOOD modules were used to model the flood routing of tributary rivers, waterlogging and lake flow inundation, and water exchanges between the lakeside, rivers, and Nansi Lake, respectively. As shown in Figure 2, the structural diagram of the NLFWSM mainly includes two components: a 2D model of Nansi Lake and its lakeside areas, and a 1D model of the river network in the lakeside area of Nansi Lake. Here, tributary rivers are called the main rivers.

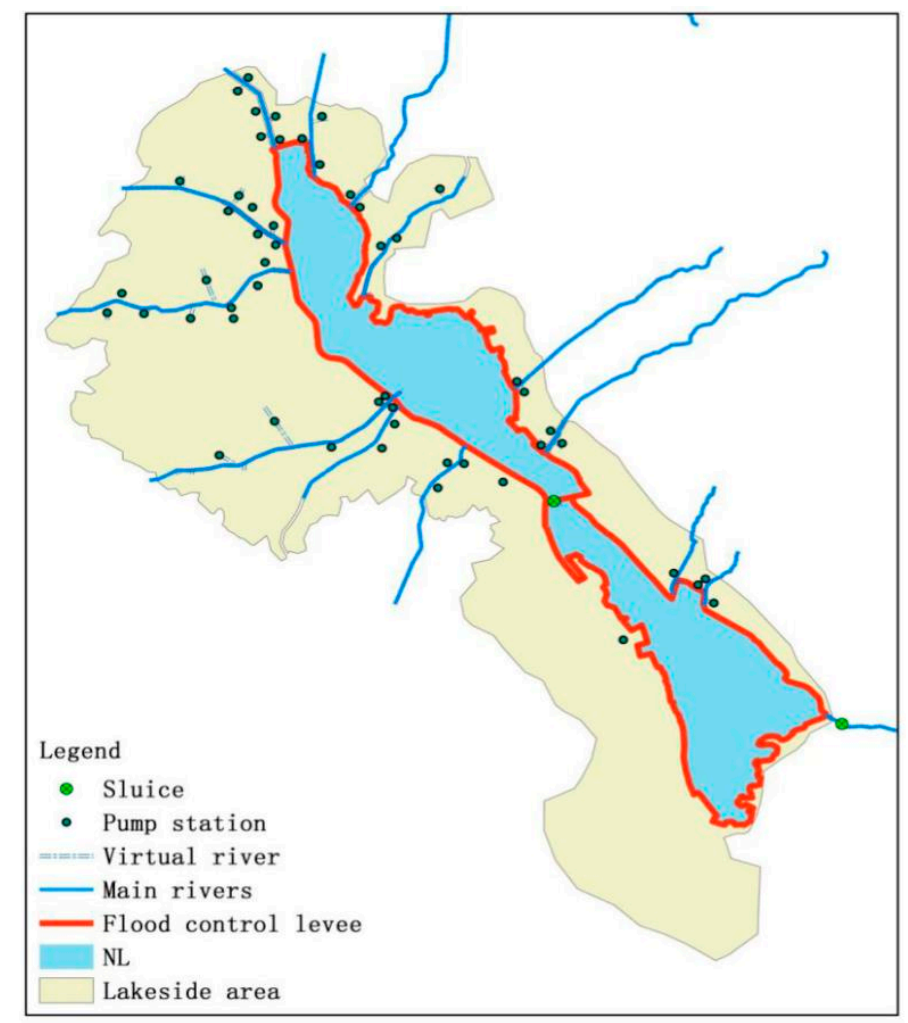

Figure 2. The structure of the Nansi Lake Flooding and Waterlogging Simulation Model.

To model the process of pumping drainage, several virtual channels with lengths of approximately 300 to $1000 \mathrm{~m}$ were added to both sides of the main rivers in the $1 \mathrm{D}$ model, and pumps were set into those channels to drain water from upstream into the main rivers. The lengths of the virtual channels varied with the distance between the pumping stations and rivers. The upper boundaries of these virtual channels were linked to their lakeside areas by standard connections to exchange the hydraulic parameters of the floodwater in the virtual channels and lakeside areas. The connection between the end of a MIKE 11 branch and a series of MIKE 21 cells or element faces were referred to as 'standard' links. During the model period, discharge was extracted from the MIKE 11 boundary, and imposed in MIKE 21 in a similar way as a MIKE 21 source discharge. The lower boundaries were linked to the main rivers so that the waterlogging water drained by pump stations could flow into the main rivers and Nansi Lake. Finally, using this method, we could simulate the drainage process of pump stations in the Nansi Lake Basin.

A 2D diffusive overland-flow model (MIKE 21) was employed to simulate the surface runoff and inundation. In the 2D model, embankment buildings were added along the sides of Nansi Lake to simulate the effects of flood control embankments around Nansi Lake. Two sluices were set up at Erji 
dam and the Han Zhuang River, the outlet of Nansi Lake, to simulate the effects of the sluice schedule on the water level in Nansi Lake and the waterlogging process in the lakeside area.

Standard connections were employed to link Nansi Lake and the main rivers to simulate the water body exchange processes between the rivers and the lake. Lateral connections were established along the main rivers to link the lakeside area and rivers. A lateral link allows a string of MIKE 21 elements to be laterally linked to a given reach in MIKE 11. Flow through the lateral link is calculated using a structural equation. This type of link is particularly useful for simulating overflow from a river channel onto a flood plain.

\subsection{D River Channel Model Set Up}

The 1D model was used to simulate the flood routing of the rivers and the drainage processes of the pumping stations in the lakeside area of Nansi Lake. There are many rivers in the Nansi Lake Basin. Given the watershed area and importance, after the collection and analysis of the data regarding the topography and locations of the main rivers, a reasonable generalization was made for those rivers. In the 1D model, 11 rivers with watershed areas above $1000 \mathrm{~km}^{2}$ and several secondary rivers were considered. The number of pumping stations with drainage discharges above one $\mathrm{m}^{3} / \mathrm{s}$ was 1001 in the lakeside area. Forty-one pumping stations were generalized in this model according to the regulation that the total drainage discharge remained unchanged in different catchment areas. The drainage discharge was controlled by the water difference between upstream and downstream according to their drainage curves. The upper boundaries of the main rivers were input into the discharge process of the design flood with various return periods, and the lower boundary was coupled with Nansi Lake.

\subsection{D Waterlogging Inundation Model Set Up}

The 2D waterlogging inundation model included Nansi Lake and its lakeside area at an elevation below $36.79 \mathrm{~m}$, covering a total area of $4750 \mathrm{~km}^{2}$. The elevation of $36.79 \mathrm{~m}$ was the boundary of the self-draining area and pumping area. The study area was subdivided based on the unstructured triangular grid mesh method, and the total number of grids was 55,339, each of which had an area of approximately 0.15 to $0.35 \mathrm{~km}^{2}$. The roughness of the grids was mainly based on the land-use type, such as water bodies, farmland, and residential areas. Design rainfalls from seven stations (Huayu, Liangshanzha, Wanglu, Wanggudui, Wangzhong, and Xuecheng) were input into the 2D model to simulate the waterlogging in the lakeside area.

The NLFWSM was established by coupling the above-mentioned 1D and 2D models using MIKEFLOOD to reflect the interactions between Nansi Lake, the main rivers, and the low-lying lakeside area. Lateral connections were adopted between the lakeside depression and the main rivers, while standard connections were adopted to link the main rivers with Nansi Lake and link virtual channels with the lakeside area. There were a total of 22 lateral connections and 52 standard connections in the NLFWSM.

\subsection{Calibration and Validation of the Nansi Lake Flooding and Waterlogging Simulation Model}

Figure 3 shows the water levels at four stations located in Nansi Lake simulated by the NLFWSM and their observed data. The roughness coefficients of the lake bed and river beds in the study area were the mainly parameters that were calibrated. Overall, there was a fairly close agreement between the simulated and observed water levels during July 2007 and July 2008. The arrival of the simulated flood peaks at different locations closely agreed with the observed data, thereby ensuring a good replication of the flood routing in the model.

The Nash-Sutcliffe efficiency coefficient (NSE), which was proposed by Nash and Sutcliffe [44], and root mean square error (RMSE) are widely used for the calibration and evaluation of hydrological and hydrodynamic models with observed data [45]. The NSE for daily flow varied from 0.67 (Erji Lake) to 0.82 (Weishan) during the calibration, and from 0.65 (Nanyang) to 0.99 (Weishan) during the verification (Table 1). The RMSE values of four water level stations were less than $0.1 \mathrm{~m}$. The error 
metrics indicate a good agreement between the observed and simulated water levels (Table 1). The small changes in the lake level constitute an important reason for the relatively low NSE values at some stations. As a result, the calibrated roughness coefficients $n$ were $0.055 \mathrm{~s} / \mathrm{m}^{1 / 3}$ for agricultural fields, $0.08 \mathrm{~s} / \mathrm{m}^{1 / 3}$ for residential areas in the lakeside area, and $0.028 \mathrm{~s} / \mathrm{m}^{1 / 3}$ for Nansi Lake.
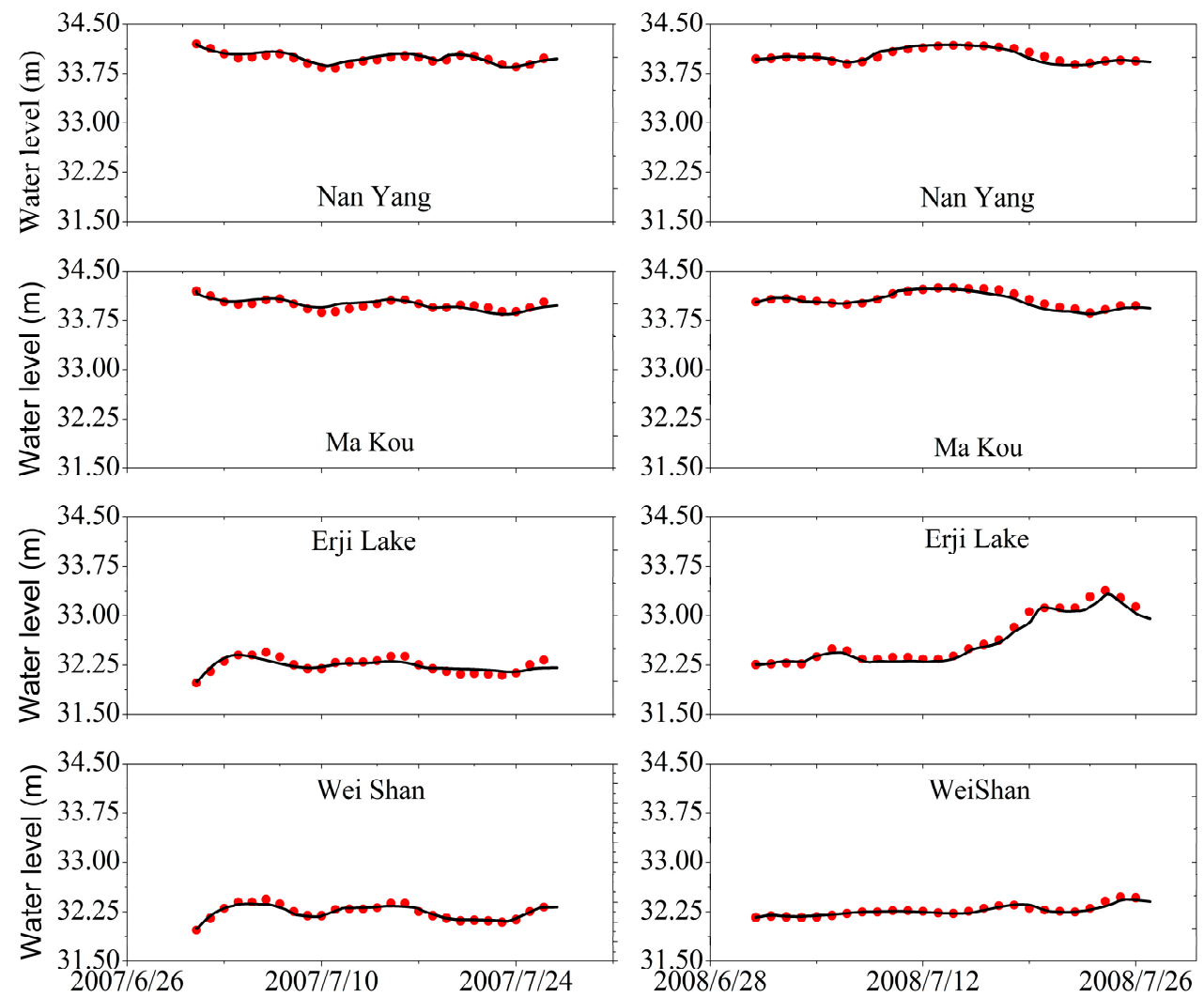

Figure 3. Comparison between the observed and simulated water levels at selected locations for flood events of 2007 under calibration conditions (left) and 2008 under validation conditions (right). Red dots represent observed data, and black lines represent the Nansi Lake Flooding and Waterlogging Simulation Model simulation results.

Table 1. Statistical evaluation of the model performance in simulating the water levels at selected gauging stations for the flood events in 2007 and 2008. NSE: Nash-Sutcliffe efficiency coefficient, RMSE: root mean square error.

\begin{tabular}{ccccc}
\hline \multirow{2}{*}{ Gauging Station } & \multicolumn{2}{c}{ NSE } & \multicolumn{2}{c}{ RMSE (m) } \\
\cline { 2 - 5 } & $\mathbf{2 0 0 7}$ & $\mathbf{2 0 0 8}$ & $\mathbf{2 0 0 7}$ & $\mathbf{2 0 0 8}$ \\
\hline Nanyang & 0.72 & 0.65 & 0.04 & 0.06 \\
Makou & 0.69 & 0.76 & 0.09 & 0.05 \\
Erji Lake(downstream) & 0.67 & 0.98 & 0.05 & 0.5 \\
Weishan & 0.82 & 0.99 & 0.07 & 0.02 \\
\hline
\end{tabular}

\section{Results and Discussions}

\subsection{Scenario Design}

The design drainage standard of the Nansi Lake Basin varies between three-year and five-year return periods of rainfall currently, and it will be promoted to approximately five to 10 years according to the planning of the low-lying lakeside area governance project. Therefore, the NLFWSM was carried 
out to simulate the rainstorm waterlogging for five-year, 10 year, and 20 year return periods. Table 2 shows the three-day design rainfall under different return periods at seven rainfall stations.

Table 2. The design rainfall of three-day duration for different return periods.

\begin{tabular}{ccccc}
\hline \multirow{2}{*}{ Stations } & \multirow{2}{*}{ Data Duration } & \multicolumn{3}{c}{ Rainfall for Three-Day Duration (mm) } \\
\cline { 3 - 5 } & & $\mathbf{2 0 \%}$ & $\mathbf{1 0 \%}$ & $\mathbf{5 \%}$ \\
\hline Liangshanzha & $1966-2008$ & 157.02 & 188.34 & 217.91 \\
Houying & $1951-2008$ & 154.67 & 188.07 & 220.11 \\
Huayu & $1967-2009$ & 141.74 & 164.42 & 184.77 \\
Wangzhong & $1957-2009$ & 148.14 & 175.87 & 202.17 \\
Wanglu & $1967-2009$ & 139.31 & 167.49 & 194.4 \\
Xuecheng & $1960-1992$ & 172.49 & 226.80 & 282.11 \\
Wanggudui & $1962-2009$ & 150.08 & 177.29 & 201.82 \\
\hline
\end{tabular}

The flood resistance depths and times of different crops are shown in Table 3 [46]. The flood resistance depth and time refer to the critical values above which the crop yields will reduce. Considering the main crop composition of the Nansi Lake Basin, the areas of the inundation depth above $10 \mathrm{~cm}$ and $50 \mathrm{~cm}$ were counted in the calculation results of different scenarios.

Table 3. Effected parameters by waterlogging.

\begin{tabular}{ccc}
\hline Crop & Resistance Inundated Time (h) & Resistance Inundated Depth (m) \\
\hline Rice & 72 & 0.5 \\
Cotton & 24 & 0.1 \\
Corn & 24 & 0.1 \\
Soybeans & 48 & 0.1 \\
\hline
\end{tabular}

The normal water level, design flood water level, and dead water level of the upper lake were $34 \mathrm{~m}, 36.5 \mathrm{~m}$, and $32.8 \mathrm{~m}$, respectively, while those water levels of the lower lake were $32.3 \mathrm{~m}, 36.0 \mathrm{~m}$, and $31.3 \mathrm{~m}$, respectively. We set three different initial lake levels to analyze the effects of WLFs on the waterlogged area around the lake; that is, the water level of Nansi Lake rises from the dead water level to the normal water level at $0.5 \mathrm{~m}$ intervals. This design can be used to not only analyze the waterlogging trend around the lake caused by increasing lake levels, but also reflect the changing characteristics of waterlogging under different initial lake levels and the same variation conditions. As a result, nine scenarios were designed (Table 4). There are many indicators, such as the inundation depth, duration time, and velocity, which can express the flood and waterlogging intensity; among them, the inundation depth is the most prevalent indicator $[47,48]$.

Table 4. Statistics of waterlogging. NL: Nansi Lake.

\begin{tabular}{|c|c|c|c|c|c|c|c|c|}
\hline \multirow{2}{*}{$\begin{array}{l}\text { Scenario } \\
\text { Number }\end{array}$} & \multirow{2}{*}{$\begin{array}{l}\text { Initial Lake } \\
\text { Level of NL }\end{array}$} & \multirow{2}{*}{$\begin{array}{l}\text { Return } \\
\text { Periods of } \\
\text { the Design } \\
\text { Rainfall }\end{array}$} & \multicolumn{2}{|c|}{ Water Depth of NL } & \multicolumn{2}{|c|}{$\begin{array}{c}\text { Inundated Depth above } \\
0.1 \mathrm{~m}\end{array}$} & \multicolumn{2}{|c|}{$\begin{array}{l}\text { Inundated Depth above } \\
0.5 \mathrm{~m}\end{array}$} \\
\hline & & & $\begin{array}{l}\text { Average } \\
\text { (m) }\end{array}$ & $\begin{array}{c}\operatorname{Max} \\
(\mathrm{m})\end{array}$ & $\begin{array}{c}\text { Total Area } \\
\left(\mathrm{km}^{2}\right)\end{array}$ & $\begin{array}{c}\text { Area Ratio } \\
(\%)\end{array}$ & $\begin{array}{l}\text { Total Area } \\
\left(\mathrm{km}^{2}\right)\end{array}$ & $\begin{array}{c}\text { Area Ratio } \\
(\%)\end{array}$ \\
\hline 1 & (1)Upper lake & 5 & 1.41 & 4.76 & 777.87 & 22.45 & 44.41 & 1.28 \\
\hline 2 & $33 \mathrm{~m}$, lower & 10 & 1.45 & 4.85 & 875.54 & 25.27 & 126.20 & 3.64 \\
\hline 3 & lake $31.3 \mathrm{~m}$ & 20 & 1.48 & 4.92 & 965.00 & 27.85 & 200.08 & 5.77 \\
\hline 4 & (2)Upper lake & 5 & 1.75 & 5.08 & 790.54 & 22.81 & 60.45 & 1.74 \\
\hline 5 & $33.5 \mathrm{~m}$, lower & 10 & 1.79 & 5.15 & 889.27 & 25.66 & 140.25 & 4.05 \\
\hline 6 & lake $31.8 \mathrm{~m}$ & 20 & 182 & 5.21 & 978.51 & 28.24 & 213.96 & 6.17 \\
\hline 7 & (3)Upper lake & 5 & 2.11 & 5.68 & 817.70 & 23.6 & 91.29 & 2.63 \\
\hline 8 & $34 \mathrm{~m}$, lower & 10 & 2.15 & 5.69 & 915.44 & 26.42 & 171.50 & 4.95 \\
\hline 9 & lake $32.3 \mathrm{~m}$ & 20 & 2.16 & 5.68 & 1001.73 & 28.91 & 242.03 & 6.98 \\
\hline
\end{tabular}

Area ratio: Percentage of inundated area in lakeside area. 


\subsection{The Influence of WLFs on the Waterlogged Area Around Lake}

As shown in Table 4, the waterlogged region in the lakeside area of Nansi Lake became larger as the rainfall intensity increased, but the amplitude decreased when the initial lake level was fixed. Taking the initial lake level of condition (1) as an example, the upper lake water level is $33 \mathrm{~m}$, and the lower lake water level is $31.3 \mathrm{~m}$. Compared with the result of Scenario 1, the inundated areas with water depths above $10 \mathrm{~cm}$ and $50 \mathrm{~cm}$ in Scenario 2 increase by $97.67 \mathrm{~km}^{2}$ and $81.79 \mathrm{~km}^{2}$, respectively. Meanwhile, the inundated areas with water depths above $10 \mathrm{~cm}$ and $50 \mathrm{~cm}$ in Scenario 3 increase by $89.46 \mathrm{~km}^{2}$ and $73.88 \mathrm{~km}^{2}$, respectively, compared with Scenario 2 . The planting area of rice, corn, soybeans, and cotton in each county of the study area is shown in Figure 4. Rice and corn are the two main crops in this area. Rice is the main crop in the eastern part of the lake, and corn is the main crop in the western part of the lake. Due to the flood resistance depth of soybeans, corn, and cotton being $10 \mathrm{~cm}$, a reduction in the yield may be observed for soybeans, corn, and other crops throughout most of the inundated area with a water depth between $10-50 \mathrm{~cm}$. The area with a waterlogging depth above $50 \mathrm{~cm}$ is relatively small, but the waterlogging losses are more serious, as waterlogging will affect the growth of rice.

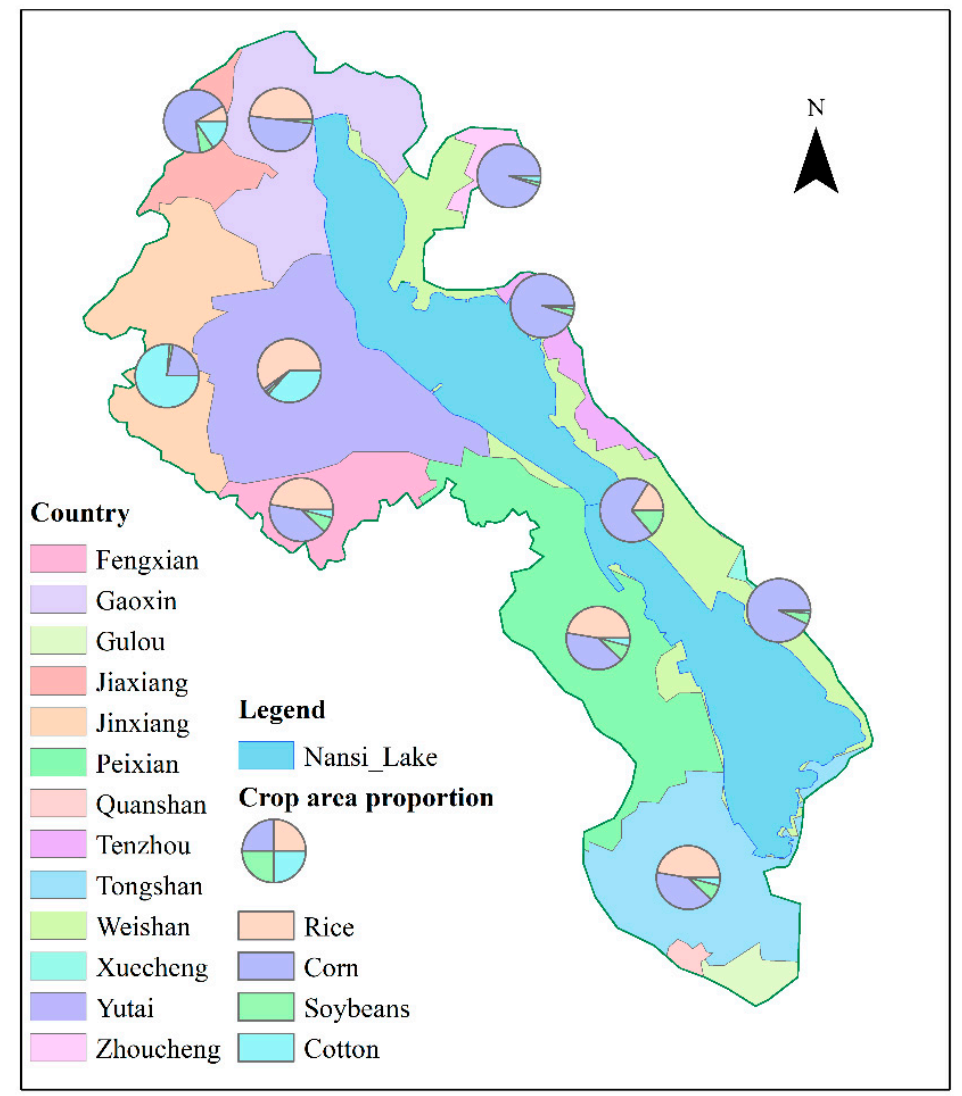

Figure 4. The crops distribution among the counties in the study area. The data comes from each county's bureau of statistics.

Under the same design rainfall scenarios (scenarios 1, 4 and 7; scenarios 2, 5 and 8; and scenarios 3,6 and 9), the waterlogged areas with inundated depths above $10 \mathrm{~cm}$ and $50 \mathrm{~cm}$ present a trend that the waterlogged area increases as the lake level rises. For instance, if the Nansi Lake Basin encounters a rainfall event with a five-year return period, when the initial water level follows condition (2), the inundated areas with water depths above $10 \mathrm{~cm}$ and $50 \mathrm{~cm}$ in Scenario 4 increase by $12.67 \mathrm{~km}^{2}$ and $16.04 \mathrm{~km}^{2}$, respectively, relative to Scenario 1 under condition (1) (Table 5). Compared with condition (2), when the initial lake level follows condition (3), the waterlogged areas with inundated depths above $10 \mathrm{~cm}$ and $50 \mathrm{~cm}$ in Scenario 7 increase by $27.16 \mathrm{~km}^{2}$ and $30.84 \mathrm{~km}^{2}$, respectively, relative to Scenario 4 
(Table 6). This result demonstrates that a rise in the lake level has obvious effects on waterlogging in the Nansi Lake lakeside area.

Table 5. The increment of the waterlogging area as the lake water level rises from condition (1) to condition (2).

\begin{tabular}{ccccccc}
\hline $\begin{array}{c}\text { Return Periods of } \\
\text { the Design } \\
\text { Rainfall }\end{array}$ & \multicolumn{2}{c}{ Area of Inundated Depth Above $\mathbf{0 . 1} \mathbf{~ m}$} & \multicolumn{3}{c}{ Inundated Depth Above $\mathbf{0 . 5} \mathbf{~ m}$} \\
\cline { 2 - 7 } & $\begin{array}{c}\text { Increment } \\
\left(\mathbf{k m}^{\mathbf{2}} \mathbf{)}\right.\end{array}$ & $\begin{array}{c}\text { Relative Increment } \\
\mathbf{( \% )}\end{array}$ & $\begin{array}{c}\text { Area Ratio } \\
\text { Increase }\end{array}$ & $\begin{array}{c}\text { Increment } \\
\mathbf{( k m}^{\mathbf{2}} \mathbf{n}\end{array}$ & $\begin{array}{c}\text { Relative Increase } \\
\mathbf{( \% )}\end{array}$ & $\begin{array}{c}\text { Area Ratio } \\
\text { Increase }\end{array}$ \\
\hline 5 & 12.67 & 1.63 & 0.37 & 16.04 & 36.12 & 0.46 \\
10 & 13.73 & 1.57 & 0.40 & 14.05 & 11.13 & 0.41 \\
20 & 13.51 & 1.40 & 0.39 & 13.88 & 6.94 & 0.40 \\
\hline
\end{tabular}

Table 6. The increment of the waterlogging area as the lake water level rises from condition (2) to condition (3).

\begin{tabular}{|c|c|c|c|c|c|c|}
\hline \multirow{2}{*}{$\begin{array}{l}\text { Return Periods of } \\
\text { the Design } \\
\text { Rainfall }\end{array}$} & \multicolumn{3}{|c|}{ Area of Inundated Depth Above $0.1 \mathrm{~m}$} & \multicolumn{3}{|c|}{ Area of Inundated Depth Above $0.5 \mathrm{~m}$} \\
\hline & $\begin{array}{c}\text { Increment } \\
\left(\mathrm{km}^{2}\right)\end{array}$ & $\begin{array}{c}\text { Relative Increase } \\
(\%)\end{array}$ & $\begin{array}{l}\text { Area Ratio } \\
\text { Increase }\end{array}$ & $\begin{array}{c}\text { Increment } \\
\left(\mathbf{k m}^{2}\right)\end{array}$ & $\begin{array}{c}\text { Relative Increase } \\
(\%)\end{array}$ & $\begin{array}{l}\text { Area ratio } \\
\text { Increase }\end{array}$ \\
\hline 5 & 27.16 & 3.44 & 3.44 & 30.84 & 51.02 & 0.89 \\
\hline 10 & 26.17 & 2.94 & 0.76 & 31.25 & 22.28 & 0.90 \\
\hline 20 & 23.22 & 2.37 & 0.67 & 28.07 & 13.12 & 0.81 \\
\hline
\end{tabular}

Tables 5 and 6 show the variable quantities of the waterlogged areas as the initial water level rises from condition (1) to condition (2) and from condition (2) to condition (3). The increase in the inundated area in Table 6 is greater than that in Table 5 under the same rainfall, which indicates that a higher lake level has a larger effect on the waterlogging in the lakeside area for the same WLFs $(0.5 \mathrm{~m})$. Taking the rainfall event with a five-year return period as an example, when the initial lake level rises from condition (1) to condition (2), the area with an inundated depth above $10 \mathrm{~cm}$ increases by $12.67 \mathrm{~km}^{2}$ with a relative increment of $1.63 \%$, and the increase in the ratio of the Nansi Lake lakeside area is $0.36 \%$. Meanwhile, the area with an inundated depth above $50 \mathrm{~cm}$ increases by $14.05 \mathrm{~km}^{2}$ with a relative increase of $31.64 \%$, and the increase in the ratio of the Nansi Lake lakeside area is $0.46 \%$. When the initial lake level rises from condition (2) to condition (3), the area with an inundated depth above $10 \mathrm{~cm}$ increases by $27.16 \mathrm{~km}^{2}$ with a relative increment of $3.44 \%$, and the increase in the ratio of the Nansi Lake lakeside area is $0.78 \%$. Meanwhile, the area with an inundated depth above $50 \mathrm{~cm}$ increases by $30.84 \mathrm{~km}^{2}$ with a relative increment of $51.02 \%$, and the increase in the ratio of the Nansi Lake lakeside area is $0.89 \%$. When the lakeside area encounters a rainfall event with a 10-year return period and the WLF is $0.5 \mathrm{~m}$, the increase of waterlogged area with an inundated depth above $10 \mathrm{~cm}$ under condition (2) $\left(26.17 \mathrm{~km}^{2}\right)$ is nearly twice as much as that under condition (1) $\left(13.73 \mathrm{~km}^{2}\right)$. When the watershed encounters a rainfall event with a 20-year return period, the change of waterlogged area has the same change rule. Figure 5 depicts the variable trends of the areas with inundated depths above $10 \mathrm{~cm}$ and $50 \mathrm{~cm}$ under different design rainfalls and lake levels, demonstrating that deeper waterlogging areas (inundated depths above $50 \mathrm{~cm}$ ) respond more sensitively to WLFs. Other rainfall scenarios have similar patterns (see Tables 5 and 6 for details). 


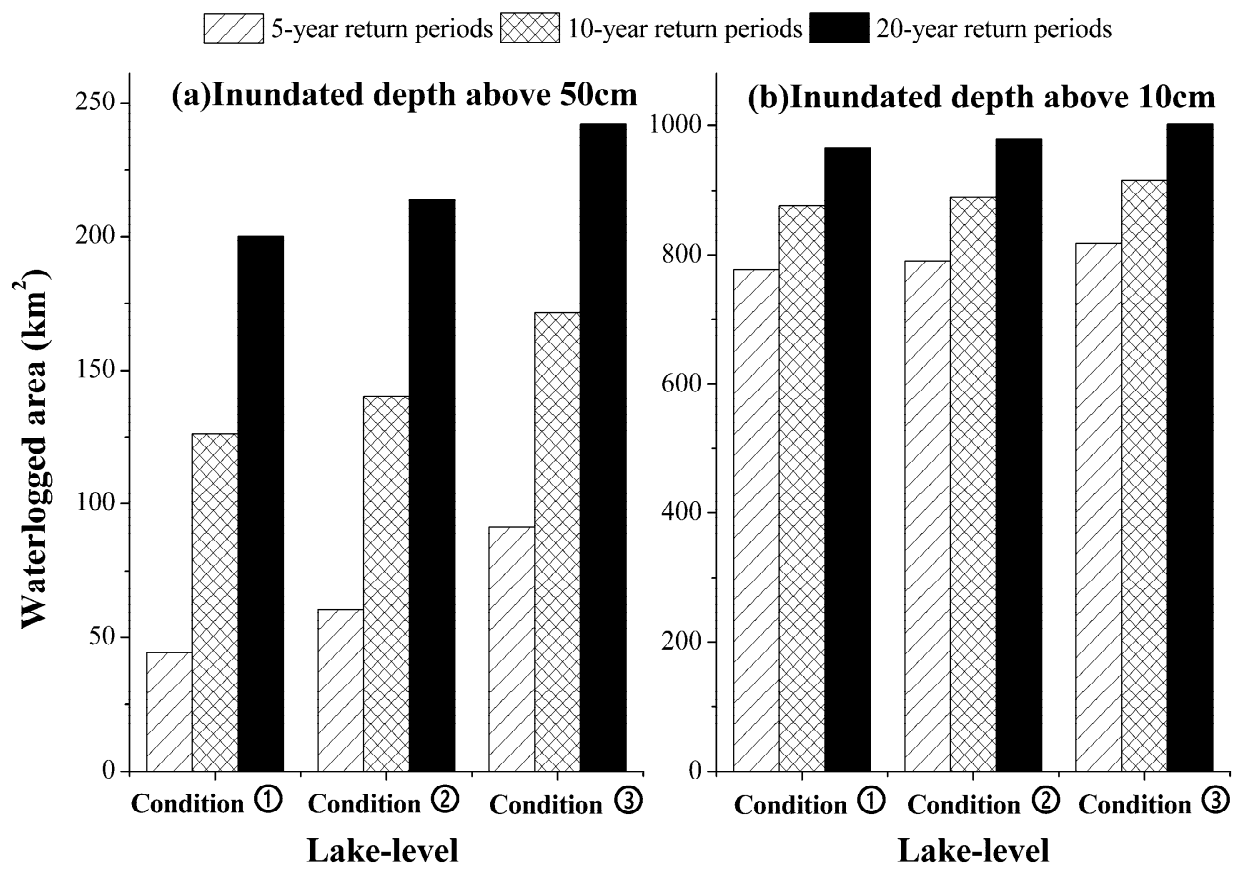

Figure 5. The changes in the area of inundation in the lakeside area according to the changes in the lake level.

4.3. The Relationship between the Waterlogged Area and the Highest Lake Level During Typical Years in Which Waterlogging Occurred in the Lakeside Area of Nansi Lake

The hydrological and hazard data of five typical waterlogging years, namely, 1954, 1957, 1963, 1991, and 1993, were collected to analyze the relationship between the waterlogged area in the Nansi Lake Basin and the water level at Nanyang station in the flood season. Figure 6 shows the change trend of the waterlogged area, which is similar to the change trend of the highest water level at Nanyang station. However, compared with 1993, the highest water level in the flooding season at Nanyang station increased obviously in 2003, but the waterlogged area in the Nansi Lake Basin did not change much. Figure 7 shows the measured water level at Nanyang station and the daily precipitation at Wanglu station from 1 July to 30 September. We can see that the lake-level peak in 2003 was basically consistent with that in 1993, but the Nansi Lake water level remained low before the lake-level rise that was caused by a rainstorm in 2003, while the lake level remained relatively high before rainfall in 1993. Combining Figures 6 and 7, we can find that although the rainfall in 1993 was less than that in 2003, the higher initial lake level before the rainstorm caused the waterlogged area in 1993 to be almost the same as that in 2003.

This analysis shows that the lake's initial water level plays an important role in the changes in the waterlogged area in the Nansi Lake Basin, suggesting that the multi-scenario simulation results are reliable. 


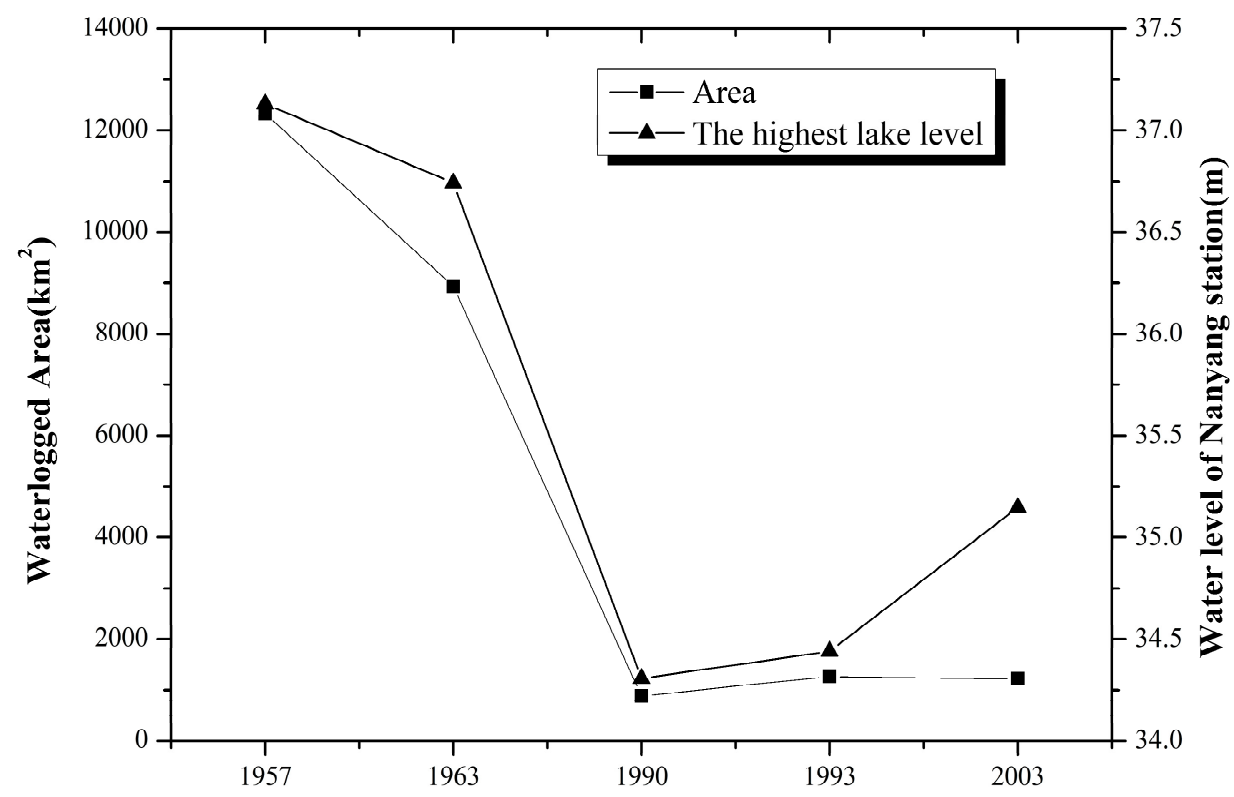

Figure 6. The comparison of the change trends of the waterlogging area and the highest water level at Nanyang station.

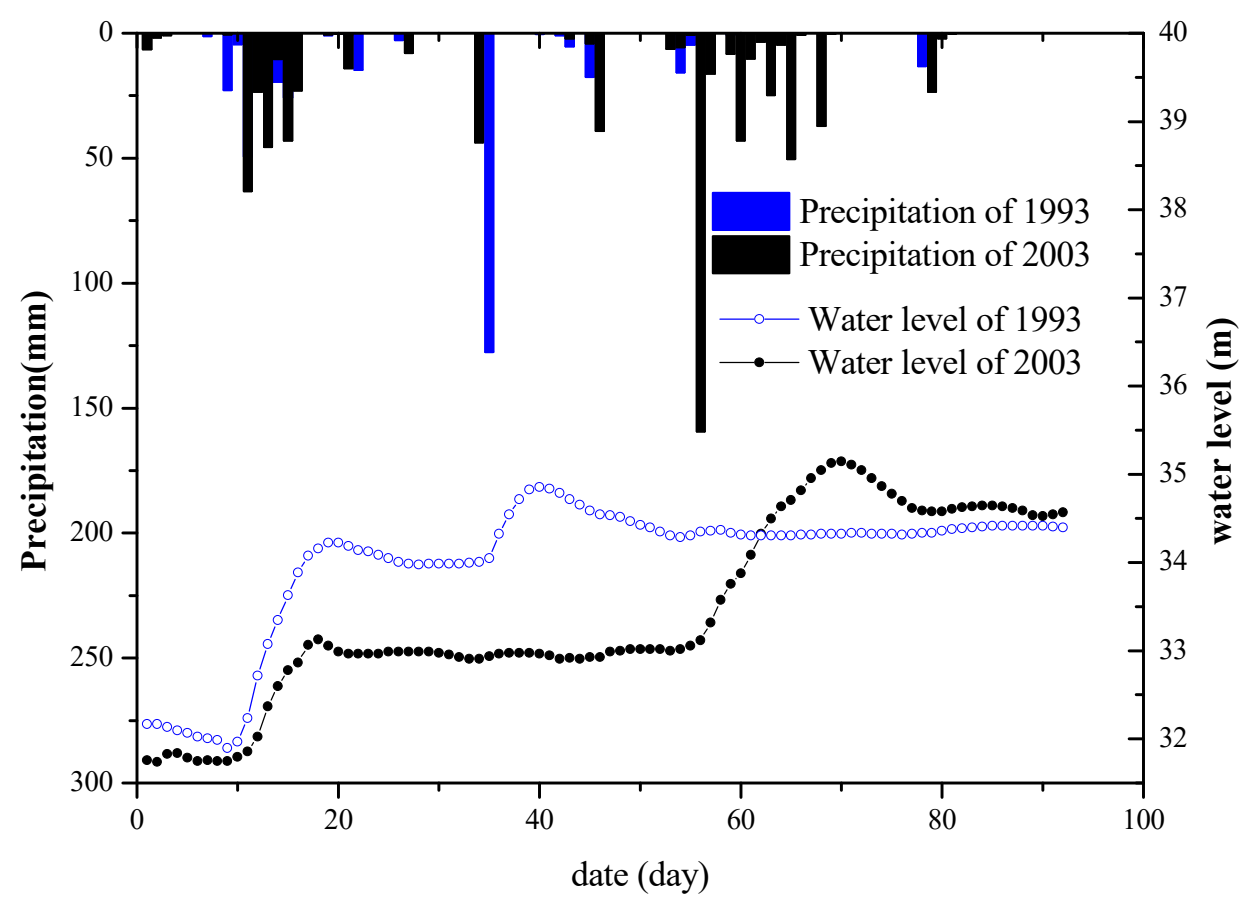

Figure 7. The water level variations at Nanyang station in typical years.

\subsection{The Differences in the Waterlogging of Different Areas around Nansi Lake in Response to WLFs}

Figure $8 \mathrm{a}, \mathrm{b}$ illustrate the distributions of the waterlogged areas with inundated depths above $10 \mathrm{~cm}$ and $50 \mathrm{~cm}$, respectively, assuming that a storm with a five-year return period occurs under lake-level condition (1). Compared with that in the eastern Nansi Lake, the lakeside area in the western Nansi Lake shows a more serious waterlogging disaster, while the waterlogging around the upper lake is more serious than that around the lower lake, which has a sporadic distribution of waterlogging. Due to the flat topography of the western Nansi Lake, the flow is slow, and thus, it is very difficult to drain the water caused by waterlogging. The reasonable excavation of drainage channels and an enlarged capacity of pumping stations are effective measures to alleviate the waterlogging hazards 
in this area. In general, the areas bounded by the Fuxin River, Dongyu River, Wanfu River, and Zhuzhaoxin River have the most serious waterlogging, and the drainage capacity in those areas should be improved. Figure 8c,d show the waterlogging statuses under initial lake-level condition (3) when a storm with a five-year return period occurs. The waterlogging distribution of condition (3) is highly similar to that of condition (1), but the increased amount of waterlogging area of the western Nansi Lake is larger than that of the eastern Nansi Lake.

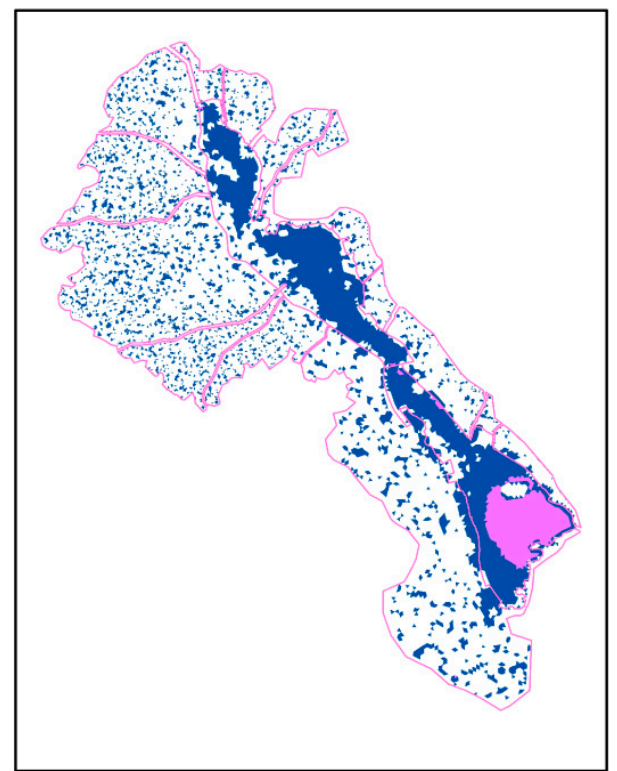

(a) The distribution of the water depth above $10 \mathrm{~cm}$ under condition (1)

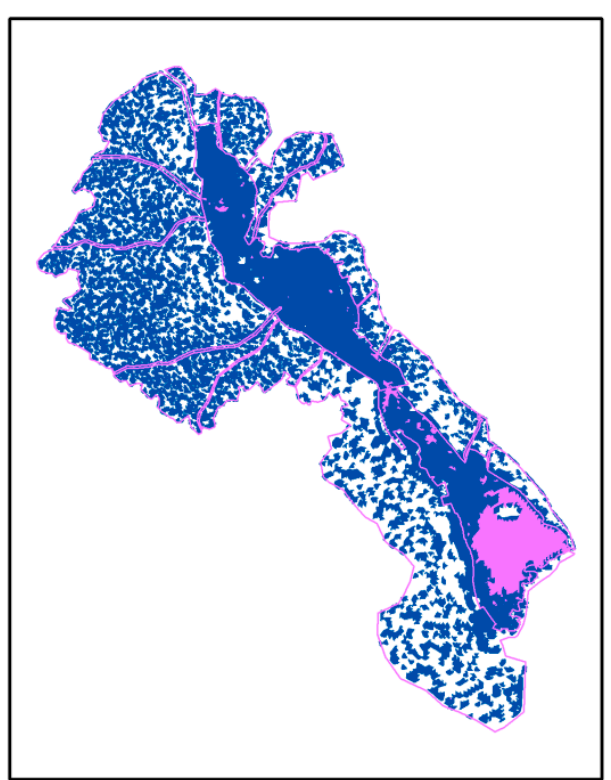

(c)The distribution of the water depth above $10 \mathrm{~cm}$ under condition (3)

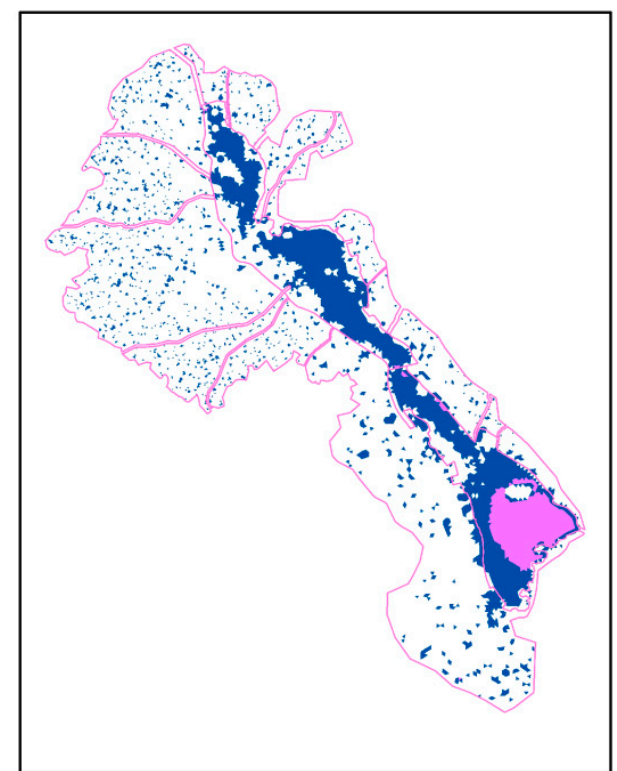

(b) The distribution of the water depth above $50 \mathrm{~cm}$ under condition (1)

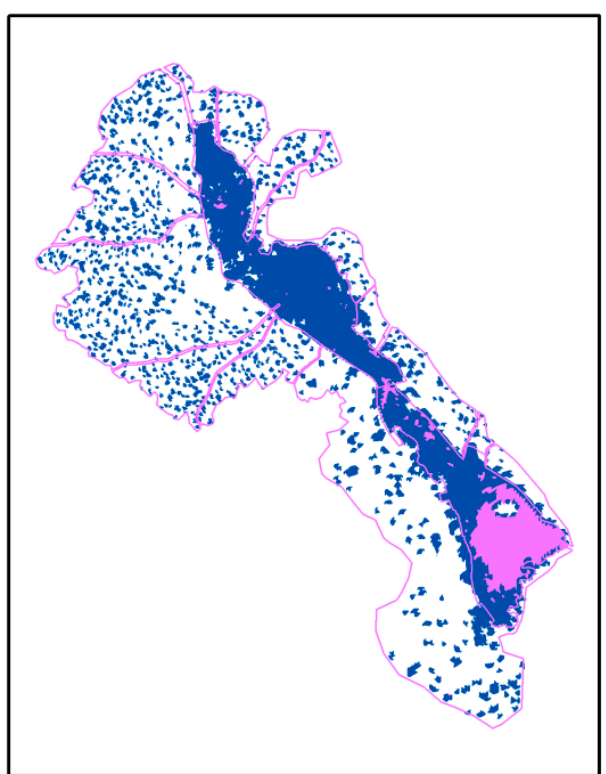

(d)The distribution of the water depth above $50 \mathrm{~cm}$ under condition (3)

Figure 8. Simulated inundation extents for a storm with a five-year return period in the Nansi Lake Basin lakeside area. The blue area around Nansi Lake represents the flooded area. The purple area in Nansi Lake is the deeper part of the lake.

To analyze the influences of changes in the lake level on waterlogging in the lakeside area, hydrographs were extracted from the results of the NLFWSM along different cross-sections of the 
Dongyu River, Wanfu River, and Zhuzhaoxin River in the western Nansi Lake, and the Si River in the eastern Nansi Lake (Figure 1). The hydrographs at the estuaries of the above rivers were also extracted from the NLFWSM (Figure 9).
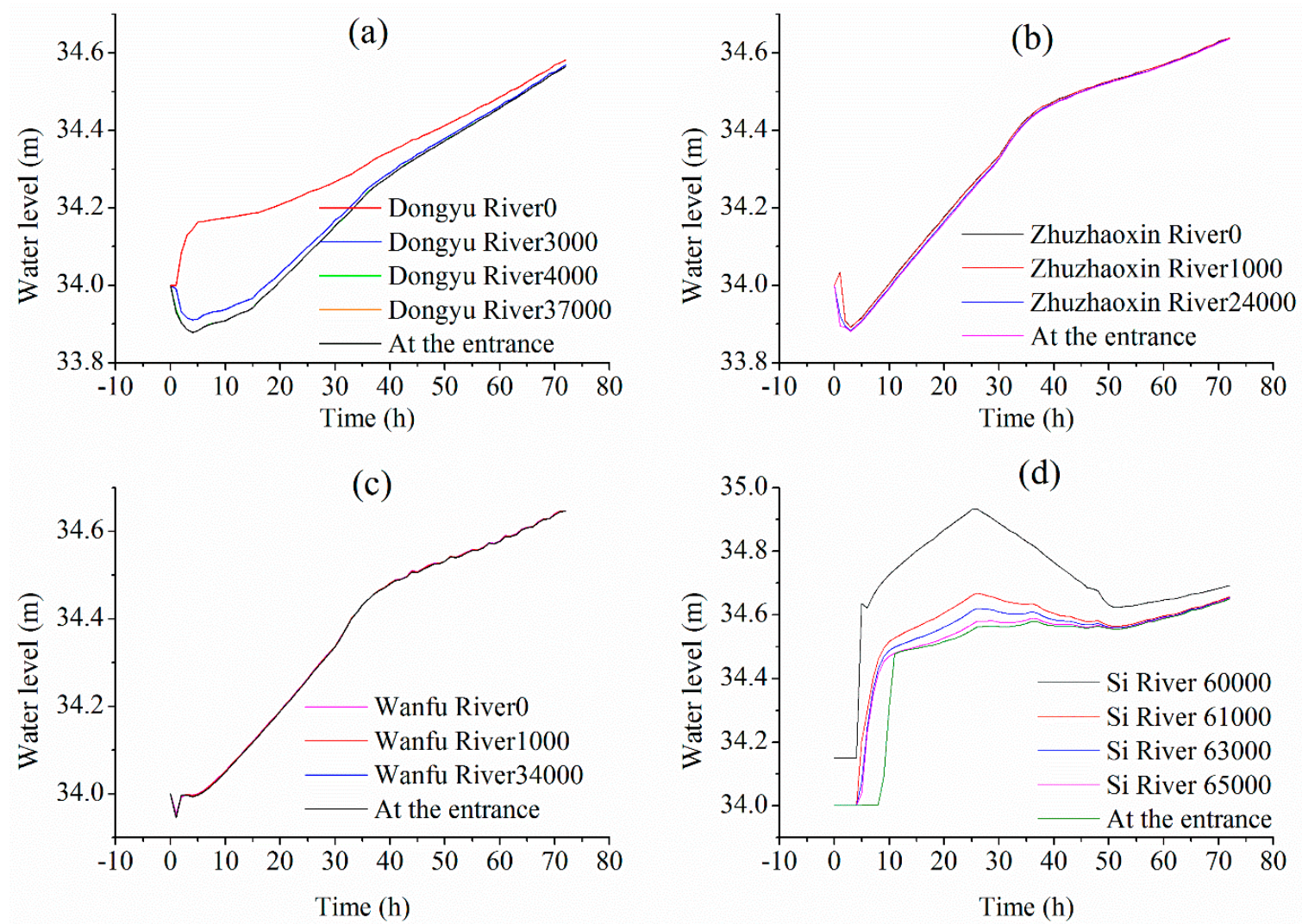

Figure 9. The water levels along different cross-sections of typical rivers entering Nansi Lake. The hydrograph stage at the entrance refers to the lake level at the entrance of each river to Nansi Lake. The numbers denote the distance between this cross-section and its starting point of a river, in which zero refers to the starting point, and the largest number refers to the entrance cross-section. For example, 'Dongyu River 0' is the starting point of this river, 'Dongyu River 37,000' refers to the entrance cross-section of Dongyu River, and 'Dongyu River 4000' indicates that this cross-section is 4000 meters away from the starting point and 33,000 meters away from the entrance cross-section.

Figure 9a shows the hydrographs at different cross-sections of the Dongyu River and the water level of Nansi Lake at the entrance of the Dongyu River, where 'Dongyu River 0' denotes the upper boundary of the Dongyu River, 'Dongyu River 35,000' represents the lower boundary, and the entrance represents the hydrograph at the estuary of the Dongyu River. Figure 9a shows that the Dongyu River is seriously affected by the water level in Nansi Lake; the hydrograph at the cross-section is situated 33,000 $\mathrm{m}$ away from Nansi Lake (Dongyu River 4000), which is exactly the same as the lake level. When the lake level is above $33.9 \mathrm{~m}, 37,000 \mathrm{~m}$ of the channel of the Dongyu River will be controlled by the water level in Nansi Lake. Figure 9a,b depict the water levels in the Zhuzhaoxin River and the Wanfu River during the simulation period. The changes in the water levels at the different cross-sections of those two rivers are basically consistent with the changes in the Nansi Lake water level, while the water levels at different cross-sections along the Si River are significantly higher than the water level of Nansi Lake. These results indicate that the tributary rivers of the western Nansi Lake have a stronger interaction with Nansi Lake than the tributary rivers in the eastern Nansi Lake.

Figure 10 shows the instantaneous water levels of four reaches at the 25th hour of the simulation from the results of scenario 1 with a simulation time of $72 \mathrm{~h}$. The highest black curves in these pictures represent the crest elevations of the embankments on both sides of the river. The lowest black 
curve denotes the bottom of those rivers, the two red dot-dash lines in the middle are the maximum and minimum water levels during the simulation process, and the blue part is the river water body. The water levels of the three channels of the Dongyu River, Wanfu River, and Zhuzhaoxin River, which are located in the western Nansi Lake, are basically consistent with the lake level. However, the water level of Nansi Lake has a small effect on the Si River, and the topography of the river is the main reason for this difference. The waterlogging around the lake in the plain area has a more sensitive response to changes in the lake level, and the lake can affect the waterlogging of the lakeside area by affecting the water levels of the tributary rivers.

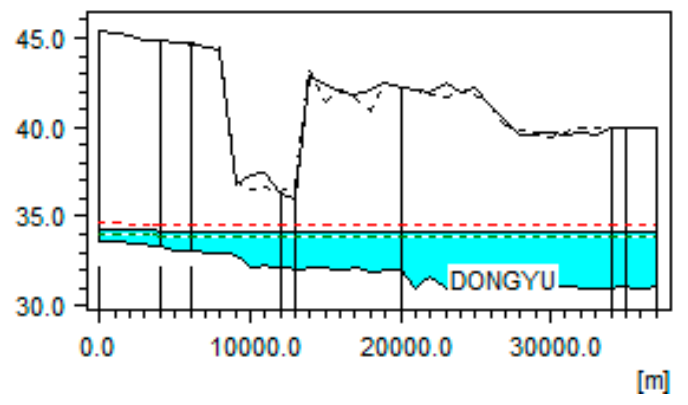

(a) Dongyu River

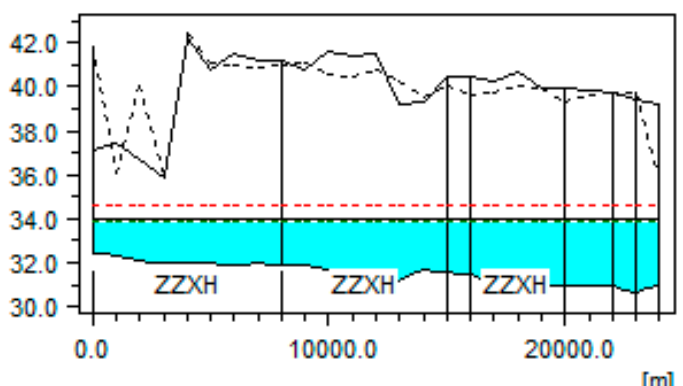

(c) Wanfu River

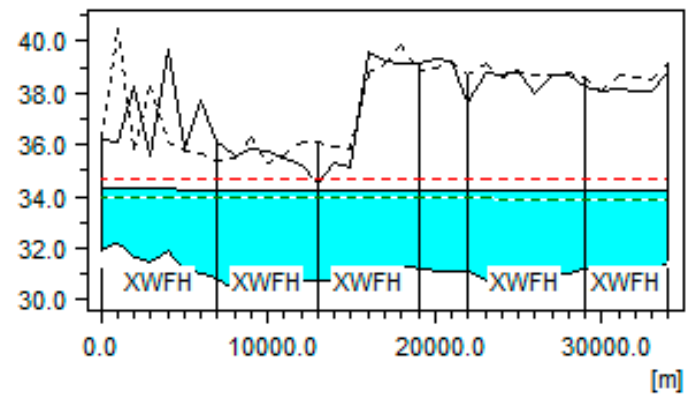

(b) Zhuzhaoxin River

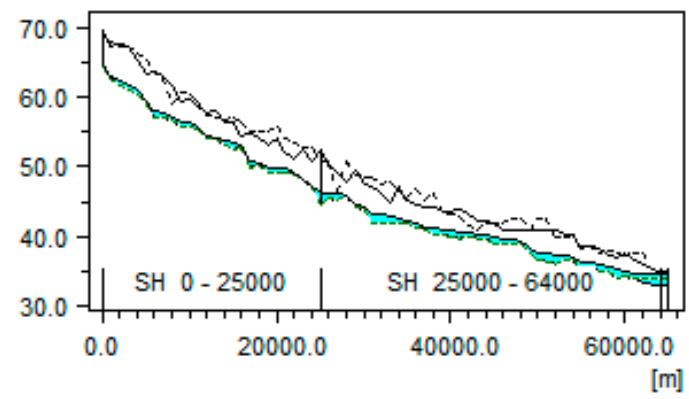

(d) Si River

Figure 10. Instantaneous water levels of typical rivers.

The above results suggest that drainage system designs and waterlogging simulations should consider the influences of the lake level fluctuations in shallow lakes located in plain areas. Redesigning and enlarging the capacities of the drainage systems or pumping stations in the lakeside areas of Nansi Lake could help reduce the effects of waterlogging disasters.

\section{Conclusions}

Frequent rainstorms during the flooding season in large-scale shallow lake basins often cause waterlogging problems. Lake-level fluctuations of shallow lakes located in plain areas have an overriding effect on the interactions between a lake and the other water bodies that are linked to it. The rise of the lake level will weaken the drainage efficiency and increase the area of inundation in lakeside areas. The present study revealed the influences of lake-level fluctuations on the waterlogged regions around lakes in plain areas.

In this paper, a 1D and 2D coupled mathematical model, namely, the NLFWSM, was established to model the waterlogging inundation around a lake and the water body interactions between the lake, tributary rivers, and lakeside area, and the preliminary application of this model in the Nansi Lake Basin was discussed. The model used virtual channels and pump stations to link the lakeside area and tributary rivers to simulate the process of waterlogging drainage, and then coupled the $1 \mathrm{D}$ and $2 \mathrm{D}$ 
models using lateral and standard connections to reflect the water interactions between the lakeside area, tributary rivers, and Nansi Lake. The model was used to compute the waterlogging of the Nansi Lake Basin under different rainfall conditions and various initial lake levels. The results show that the model can simulate the waterlogging and the interactions among the lakeside area, tributary rivers, and Nansi Lake well. The waterlogging of the lakeside area is sensitive to changes in the lake level; furthermore, for the same increase in the lake level, a higher initial lake level corresponds to a larger increase in the waterlogged area in the lakeside area. The inundated area with a submerged depth of greater than $50 \mathrm{~cm}$ shows a larger increase than the area with a submerged depth of greater than $10 \mathrm{~cm}$ for the same water level rise in Nansi Lake. The waterlogging in areas with a low terrain and flat slope will respond more sensitively to a change in the lake level.

There is a need to improve upon the existing research on the submerged depth and inundation area, which cannot completely reflect the extent of waterlogging. If the vulnerability of hazard-bearing bodies can be considered to supplement the population and gross domestic product (GDP) data of the study area to reflect the extent of waterlogging, the results will be more persuasive. In addition, although the 2D hydrodynamic model can simulate the space-time process of waterlogging around Nansi Lake, it is difficult to simulate the waterlogging of the whole Nansi Lake Basin because of the limitations of the computational efficiency of the model. Conducting a case study with a combined hydrological and hydrodynamic model to simulate the waterlogging and flooding in the Nansi Lake Basin and their interactions with Nansi Lake would be very meaningful. For a large shallow lake, the changes in the water level and their impact on flood control and waterlogging drainage are decisive factors on the water resources and water environment; therefore, using adaptive regulations to control the lake water level to balance the water resources and waterlogging disasters in lake basins constitutes another important issue. In future work, if we can obtain the measured distribution of waterlogging in the Nansi Lake Basin through remote sensing data such as MODIS to verify the spatial distribution of the simulated results in the 2D model, the accuracy of the model will be further improved.

Author Contributions: Conceptualization, Z.W. and K.L.; Methodology, Z.W and K.L.; Software, K.W. and A.Y.; Validation, K.W.; Formal Analysis, Z.W. and K.W.; Investigation, L.C. and L.W.; Resources, Z.W. and K.L. and L.C.; Writing - Original Draft Preparation, Z.W., K.W. and K.L.; Writing - Review \& Editing, L.C., L.W. and A.Y.; Visualization, Z.W. and K.W.; Project Administration, L.W. and L.C.; Funding Acquisition, Z.W. and K.L and L.C. All authors are contributed to the final version of the manuscript.

Funding: This study was financial supported by the National Key Research and Development Program of China (2017YFC0403504), the National Science Foundation of China under Grants (No.51479119 and 51579064).

Acknowledgments: Authors thank to the Planning and Design Institute of the Huaihe Basin Hydraulic Management Bureau in Shandong Province and the Shandong Provincial Hydrology Bureau for providing the study data.

Conflicts of Interest: The authors declare no conflict of interest.

\section{References}

1. Verpoorter, C.; Kutser, T.; Seekell, D.A.; Tranvik, L.J. A global inventory of lakes based on high-resolution satellite imagery. Geophys. Res. Lett. 2014, 41, 6396-6402. [CrossRef]

2. London, J.; Oltmans, S.J. The global distribution of long-term total ozone variations during the period 1957-1975. Pure Appl. Geophys. 1978, 117, 345-354. [CrossRef]

3. Coops, H.; Beklioglu, M.; Crisman, T.L. The role of water-level fluctuations in shallow lake ecosystemsWorkshop conclusions. Hydrobiologia 2003, 506, 23-27. [CrossRef]

4. Beklioglu, M.; Altinayar, G.; Tan, C.O. Water level control over submerged macrophyte development in five shallow lakes of Mediterranean Turkey. Arch. für Hydrobiol. 2006, 166, 535-556. [CrossRef]

5. G.O.P, O. Bulletin of the American Meteorological Society. Bull. Am. Meteorol. Soc. 1994, 75, 1655-1661.

6. McIntyre, J.W. Loons in freshwater lakes. Hydrobiologia 1994, 279, 393-413. [CrossRef]

7. Furey, P.; Nordin, R.; Mazumder, A. Water Level Drawdown Affects Physical and Biogeochemical Properties of Littoral Sediments of a Reservoir and a Natural Lake. Lake Reserv. Manag. 2004, 20, 280-295. [CrossRef] 
8. Nowlin, W.H.; Davies, J.M.; Nordin, R.N.; Mazumder, A. Effects of water level fluctuation and short-term climate variation on thermal and stratification regimes of a British Columbia reservoir and lake. Lake Reserv. Manag. 2004, 20, 91-109. [CrossRef]

9. Fischer, P.; Öhl, U. Effects of Water-Level Fluctuations on the Littoral Benthic Fish Community in Lakes: A Mesocosm Experiment. Behav. Ecol. 2005, 16, 741-746. [CrossRef]

10. White, M.S.; Xenopoulos, M.A.; Hogsden, K.; Metcalfe, R.A.; Dillon, P.J. Natural lake level fluctuation and associated concordance with water quality and aquatic communities within small lakes of the Laurentian Great Lakes region. Hydrobiologia 2008, 613, 21-31. [CrossRef]

11. Rasid, H.; Hufferd, J. Hazards of living on the edge of water: The case of Minnesota Point, Duluth, Minnesota. Hum. Ecol. 1988, 17, 85-100. [CrossRef]

12. Clausen, J.C.; Johnson, G.D. Lake Level Influences on Sediment and Nutrient Retention in a Lakeside Wetland. J. Environ. Qual. 1990, 19, 83-88. [CrossRef]

13. Luo, W.; Wang, X.; Luo, Q.; Zhang, X. Effects of underlying surface changes on drainage modulus in Four-lake Watershed. Adv. Water Sci. 2014, 25, 275-281.

14. Guo, H.; Hu, Q.; Zhang, Q.; Feng, S. Effects of the Three Gorges Dam on Yangtze River flow and river interaction with Poyang Lake, China: 2003-2008. J. Hydrol. 2012, 416-417, 19-27. [CrossRef]

15. Li, X.; Zhang, Q. Variation of floods characteristics and their responses to climate and human activities in Poyang Lake, China. Chinese Geogr. Sci. 2015, 25, 13-25. [CrossRef]

16. Sivapalan, M.; Blöschl, G. Transformation of point rainfall to areal rainfall: Intensity-duration-frequency curves. J. Hydrol. 1998, 204, 150-167. [CrossRef]

17. Yin, Z.; Yin, J.; Xu, S.; Wen, J. Community-based scenario modelling and disaster risk assessment of urban rainstorm waterlogging. J. Geogr. Sci. 2011, 21, 274-284. [CrossRef]

18. Wu, X.; Yu, D.; Chen, Z.; Wilby, R.L. An evaluation of the impacts of land surface modification, storm sewer development, and rainfall variation on waterlogging risk in Shanghai. Nat. Hazard 2012, 63, 305-323. [CrossRef]

19. Yang, M.; Xu, Y.; Pan, G.; Han, L. Impacts of Urbanization on Precipitation in Taihu, China. J. Hydrol. Eng. 2014, 19, 739-746. [CrossRef]

20. Li, X.; Zhang, Q.; Xu, C.-Y.; Ye, X. The changing patterns of floods in Poyang Lake, China: Characteristics and explanations. Nat. Hazard 2015, 76, 651-666. [CrossRef]

21. Karl, T.R.; Knight, R.W. Secular Trends of Precipitation Amount, Frequency, and Intensity in the United States. Bull. Am. Meteorol. Soc. 1998, 79, 231-241. [CrossRef]

22. Partal, T.; Kahya, E. Trend analysis in Turkish precipitation data. Hydrol. Process. 2006, 20, 2011-2026. [CrossRef]

23. Douglas, E.M.; Fairbank, C.A. Is Precipitation in Northern New England Becoming More Extreme? Statistical Analysis of Extreme Rainfall in Massachusetts, New Hampshire, and Maine and Updated Estimates of the 100-Year Storm. J. Hydrol. Eng. 2011, 16, 203-217. [CrossRef]

24. Haylock, M.; Nicholls, N. Trends in Extreme Rainfall Indices for an Updated High Quality Data Set for Australia, 1910-1998. Int. J. Climatol. 2000, 20, 1533-1541. [CrossRef]

25. Bisht, D.S.; Chatterjee, C.; Kalakoti, S.; Upadhyay, P.; Sahoo, M.; Panda, A. Modeling urban floods and drainage using SWMM and MIKE URBAN: A case study. Nat. Hazard 2016, 84, 749-776. [CrossRef]

26. Quan, R.-S. Rainstorm waterlogging risk assessment in central urban area of Shanghai based on multiple scenario simulation. Nat. Hazard 2014, 73, 1569-1585. [CrossRef]

27. Shi, Y. Population vulnerability assessment based on scenario simulation of rainstorm-induced waterlogging: A case study of Xuhui District, Shanghai City. Nat. Hazard 2013, 66, 1189-1203. [CrossRef]

28. Yin, J.; Yu, D.; Yin, Z.; Wang, J.; Xu, S. Multiple scenario analyses of Huangpu River flooding using a 1D/2D coupled flood inundation model. Nat. Hazard 2013, 66, 577-589. [CrossRef]

29. Wang, Z.; Wu, J.; Cheng, L.; Liu, K.; Wei, Y.M. Regional flood risk assessment via coupled fuzzy c-means clustering methods: an empirical analysis from China's Huaihe River Basin. Nat. Hazard 2018, 93, 803-822. [CrossRef]

30. Gironás, J.; Roesner, L.A.; Rossman, L.A.; Davis, J. A new applications manual for the Storm Water Management Model (SWMM). Environ. Model. Softw. 2010, 25, 813-814. [CrossRef]

31. Rossman, L. Redevelopment of the US EPA Stormwater Management Model. Proc. Water Environ. Fed. 2003, 10, 579-589. [CrossRef] 
32. Hsu, M.H.; Chen, S.H.; Chang, T.J. Inundation simulation for urban drainage basin with storm sewer system. J. Hydrol. 2000, 234, 21-37. [CrossRef]

33. Ghimire, S. Application of a 2D Hydrodynamic Model for Assessing Flood Risk from Extreme Storm Events. Climate 2013, 1, 148-162. [CrossRef]

34. Karim, F.; Petheram, C.; Marvanek, S.; Ticehurst, C.; Wallace, J.; Hasan, M. Impact of climate change on floodplain inundation and hydrological connectivity between wetlands and rivers in a tropical river catchment. Hydrol. Process. 2016, 30, 1574-1593. [CrossRef]

35. Dutta, D.; Herath, S.; Musiake, K. A mathematical model for flood loss estimation. J. Hydrol. 2003, 277, $24-49$. [CrossRef]

36. Li, W.; Xu, B.; Wen, J. Scenario-based community flood risk assessment: a case study of Taining county town, Fujian province, China. Nat. Hazard 2016, 82, 193-208. [CrossRef]

37. Xu, L.G.; Li, L.H.; Jiang, J.H.; Wan, J.B. Impacts of water level fluctuation on the flood disaster around Poyang Lake. In Proceedings of the 2013 3rd International Conference on Intelligent System Design and Engineering Applications, Hong Kong, China, 10-18 January 2013.

38. She, D.; Xia, J.; Zhu, L.; Lü, J.; Chen, X.; Zhang, L.; Zhang, X. Changes of rainfall and its possible reasons in the Nansi Lake Basin, China. Stoch. Environ. Res. Risk Assess. 2016, 30, 1099-1113. [CrossRef]

39. Schneider, P.; Hook, S.J. Space observations of inland water bodies show rapid surface warming since 1985. Geophys. Res. Lett. 2010, 37, 1-5. [CrossRef]

40. Wolf, T.J.; Morrison, T.; Matheson, L. Initial development of a work-related assessment of dysexecutive syndrome: The Complex Task Performance Assessment. Work 2008, 31, 221-228.

41. Iestyn Woolway, R.; Merchant, C.J. Amplified surface temperature response of cold, deep lakes to inter-annual air temperature variability. Sci. Rep. 2017, 7, 1-8.

42. An, W.C.; Li, X.M. Phosphate adsorption characteristics at the sediment-water interface and phosphorus fractions in Nansi Lake, China, and its main inflow rivers. Environ. Monit. Assess. 2009, 148, 173-184. [CrossRef] [PubMed]

43. DHI. MIKE 11: A Modelling System for Rivers and Channels; User Guide; Danish Hydraulic Institute: Hørsholm, Denmark, 2007.

44. Nash, J.E.; Sutcliffe, J.V. River flow forecasting through conceptual models Part I-A discussion of principles. J. Hydrol. 1970, 10, 282-290. [CrossRef]

45. Gupta, H.V.; Kling, H.; Yilmaz, K.K.; Martinez, G.F. Decomposition of the mean squared error and NSE performance criteria: Implications for improving hydrological modelling. J. Hydrol. 2009, 377, 80-91. [CrossRef]

46. Wang, Y. Waterlogged Disaster in The Huaihe Basin and Its Management; Science Press: Beijing, China, 2015; ISBN 978-7-03-043690-0.

47. Wind, H.G.; Nierop, T.M.; de Blois, C.J.; de Kok, J.L. Analysis of flood damages from the 1993 and 1995 Meuse Floods. Water Resour. Res. 1999, 35, 3459-3465. [CrossRef]

48. Merz, B.; Thieken, A.H. Flood risk curves and uncertainty bounds. Nat. Hazard 2009, 51, 437-458. [CrossRef]

(c) 2019 by the authors. Licensee MDPI, Basel, Switzerland. This article is an open access article distributed under the terms and conditions of the Creative Commons Attribution (CC BY) license (http:/ / creativecommons.org/licenses/by/4.0/). 